NBER WORKING PAPER SERIES

CORPORATE CULTURE, SOCIETAL CULTURE, AND INSTITUTIONS

Luigi Guiso

Paola Sapienza

Luigi Zingales

Working Paper 20967

http://www.nber.org/papers/w20967

\author{
NATIONAL BUREAU OF ECONOMIC RESEARCH \\ 1050 Massachusetts Avenue \\ Cambridge, MA 02138 \\ February 2015
}

The views expressed herein are those of the authors and do not necessarily reflect the views of the National Bureau of Economic Research.

NBER working papers are circulated for discussion and comment purposes. They have not been peerreviewed or been subject to the review by the NBER Board of Directors that accompanies official NBER publications.

(C) 2015 by Luigi Guiso, Paola Sapienza, and Luigi Zingales. All rights reserved. Short sections of text, not to exceed two paragraphs, may be quoted without explicit permission provided that full credit, including $(\odot$ notice, is given to the source. 
Corporate Culture, Societal Culture, and Institutions

Luigi Guiso, Paola Sapienza, and Luigi Zingales

NBER Working Paper No. 20967

February 2015

JEL No. K4,Z1

\section{ABSTRACT}

While both cultural and legal norms (institutions) help foster cooperation, culture is the more primitive of the two and itself sustains formal institutions. Cultural changes are rarer and slower than changes in legal institutions, which makes it difficult to identify the role played by culture. Cultural changes and their effects are easier to identify in simpler, more controlled, environments, such as corporations. Corporate culture, thus, is not only interesting per se, but also as a laboratory to study the role of societal culture and the way it can be changed.

Luigi Guiso

Axa Professor of Household Finance

Einaudi Institute for Economics and Finance

Via Sallustiana 62 - 00187

Rome, Italy

luigi.guiso@eief.it

Paola Sapienza

Kellogg School of Management

Northwestern University

2001 Sheridan Road

Evanston, IL 60208

and CEPR

and also NBER

paola-sapienza@northwestern.edu
Luigi Zingales

Booth School of Business

The University of Chicago

5807 S. Woodlawn Avenue

Chicago, IL 60637

and NBER

luigi.zingales@ChicagoBooth.edu 


\title{
Corporate Culture, Societal Culture, and Institutions
}

\author{
By Luigi Guiso, PaOla SAPIENZA AND Luigi ZingaLeS
}

While both cultural and legal norms (institutions) help foster cooperation, culture is the more primitive of the two and itself sustains formal institutions. Cultural changes are rarer and slower than changes in legal institutions, which makes it difficult to identify the role played by culture. Cultural changes and their effects are easier to identify in simpler, more controlled, environments, such as corporations. Corporate culture, thus, is not only interesting per se, but also as a laboratory to study the role of societal culture and the way it can be changed.

* Luigi Guiso: Einaudi Institute for Economics and Finance, Via Sallustiana 62, 00187 Rome, Italy (e-mail: guiso@tin.it); Paola Sapienza: Kellogg School of Management, Northwestern University, 2001 Sheridan Road, Evanston, IL 60208 (e-mail: paolasapienza@kellogg.northwestern.edu); Luigi Zingales: The University of Chicago, Booth School of Business, 5807 South Woodlawn Avenue, Chicago, $\quad$ IL 60637 mail: luigi.zingales@chicagobooth.edu.

According to North (1991) institutions foster cooperation in settings without full information and repeated interaction. North classifies institutions in informal (sanctions, taboos, customs, traditions, and codes of conduct) and formal (constitutions, laws, property rights). Informal institutions, which we will refer to as culture, comprise societal values (which affects intrinsic motivations) and social norms. In primitive and simple societies, where personal ties and ostracism are enough to enforce cooperation, culture is the only mechanism. Intrinsic motivation and social norms work well when the rules they prescribe are simple to apply, when they are widely shared, and when social sanction (ostracism or exclusion) is a powerful threat. While these conditions hold in small primitive societies, in most modern societies, they do not. To function modern economies need rules that take into account many contingencies. These complex rules make the verification process difficult requiring specialized (and dedicated) agents. Also, the development of long distance trade requires more impersonal contract enforcement mechanisms that are formalized through political and legal institutions. When economies evolve, formal institutions replace many informal mechanisms of enforcement. Indeed, a dominant thesis argues that the economic success of nations is not driven by culture or value systems but rather by inclusive political institutions (Acemoglu et al., 2001) or by effective legal institution (La Porta, et al., 1998). 


\section{Culture Matters}

Yet, evidence shows that culture still plays a direct role even in societies characterized by sophisticated formal institutions. Guiso et al. (2004) show that more cooperative social norms affect the use and the availability of financial contracts in Italy. Social norms not only affect individual beliefs and expectations, but are also transmitted to future generations (Bisin and Verdier, 2000; Tabellini, 2008), as the literature on the behavior of immigrants has documented (e.g. Giuliano, 2007; Guiso et al. (2006), Algan and Cahuc, 2010). This intergenerational transmission is what makes culture so persistent (Guiso et al., 2008a). One culturally-determined dimension is generalized trust (GS), the expectation that a random member of an identifiable group is trustworthy (Guiso et al., 2009). GS is correlated not only with aggregate economic outcomes, but also with micro ones. For example, Guiso et al. (2008b) shows that individual trust towards others helps explain stock market participation in modern societies, especially among the wealthy. The evidence that cultural norms and beliefs affect economic behavior together with the evidence documenting the long lasting effect of social norms (Nunn and Wantchekon, 2011, Voigtländer and Voth (2012), Grosjean (2011), and Alesina et al. (2013), Guiso et al. (2008a)) suggest that culture must play a role in explaining persistent differences in the economic success or failure of nations. But how does it relate to legal institutions?

\section{Culture As a Primitive}

La Porta et al. (2008) identify a remarkable pattern of correlations between a country legal origins and its protection of property rights. They attribute it to the difference in legal traditions. To what extent this difference simply reflects cultural differences? After all, many countries (such as Japan and China) chose which legal tradition to adopt based on cultural affinities. Others, for the same reason, shifted legal traditions (like Italy). Similarly, Acemoglu et al. (2001), attribute economic success to the type of legal institutions designed by the colonizing power. Yet, if this was the only factor, it would suffice to imitate the U.S. constitution to prosper. Many Latin American countries tried and failed. Social norms are needed to sustain legal norms. When laws are in conflict with norms compliance and enforcement are weaker (Acemoglu and Jackson, 2014). In the United States the cultural foundation of the law is illustrated by the power of the jury to disregard the law in convicting or absolving (jury nullification). 


\section{Direction of Causality}

Thus, culture underpins and color the law, but legal institution can shape cultural norms. Despite the abundant literature on the role of culture, it is difficult to sort out the direction of causality. One of the key issues is where culture comes from. One source is production technology, such as the plough (Alesina et al., 2013). Another is a politically or military shocks like slave-trader' raids (Nunn and Wantchekon, 2011), a despotic foreign domination (Putnam, 1993; Guiso et al.; 2008a; Grosjean, 2011) or the adoption (or imposition) of a new religion (e.g. Basten and Betz, 2013). But these "cultural revolutions" are rare events, often taking place over several centuries with many other things occurring at the same time. Lacking sufficient observations of cultural changes, to try identify the effects of culture on economic (and other) outcomes economists have compared the behavior of individuals who live in the same country or region (and thus share the same institutional environment) but moved their from countries or regions with different cultures (e.g. Guiso et al. 2004), relying on the fact that culture, differently from institutions, moves with individuals and persists. This empirical strategy allows to contrast how behavior varies as culture differs across individuals but says nothing about what leads culture to change. Yet, without a clear knowledge of what triggers cultural change and how new norms and beliefs replace older ones, it is impossible to understand whether and when cultural norms can be relied upon as policy instruments and how they relate to legal norms. Do cultural norms crowd out or strengthen legal norms? Which type of norms - cultural or legal - is more effective in pursuing a certain policy, such as increasing tax compliance or fighting corruption? If new cultural norms and beliefs clash against existing ones, how does the political economy of cultural revolutions works?

The role of culture and the process that leads it to change has a greater hope to be identified and understood where the environment is simpler, culture can change at a higher frequency, and it is easier to identify the agent that can trigger the change. Corporations provide such an environment.

\section{The Corporate Culture Lab}

Corporations are micro societies. At a smaller scale, they share the same challenge to foster cooperation. As larger societies, they try to use both intrinsic motivations and norms (Kreps (1990), Kreps (1997), O'Reilly and Chatman (1996), Erhard et al (2007), Guiso et al. (2014)), as well as formal incentives (compensation schemes and promotion), 
which can be thought of as the formal institutions of a corporation. Unlike large societies, however, corporations give hopes to identify the link between culture and formal institutions.

First, the creation of a firm is a moment where the founder has the power to set values on a blank slate. Identification of this moment is easier (it is recorded, it is recent) than identifying when and who sets the values of a large community (e.g. a country). Second, culture is easier to change in a corporation. Through hiring and firing corporations can select values by selecting people, avoiding the more difficult strategy of changing their minds. And can punish them if they do not adapt (e.g. by deferring promotion). In large societies only the difficult strategy is available, and slow adaptation is hard to punish, unless slow-adapters are outlawed, which makes culture and law undistinguishable. Third, it is easier to establish the link with performance. Performance is continuously recorded, for the corporation as a whole and often for its segments and divisions in order to implement compensation schemes. Hence, one can study the role of shared norms and beliefs while controlling for the power of economic incentives. Finally, because firms break up and merge much more often than countries, an observer can collect exposure of a firm to a new culture much more often than one can for larger societies.

\section{Conclusions}

In the last twenty years, economists have resorted to the role of institutions to explain the causes of national prosperity. Thus far, the emphasis has been on formal institutions. We claim that informal institutions (culture) are at least as important. While disentangling the effect of the two is difficult in large societies, it can be done inside corporations. Thus, corporate culture is not only interesting per se, but also as a laboratory to study the role of societal culture and the way it can be changed.

\section{REFERENCES}

Acemoglu, Daron and Matthew Jackson,. 2014. "Social Norms and the Enforcement of Laws," working paper.

Acemoglu, Daron, Simon Johnson and James A. Robinson. 2001. "The Colonial Origins of Comparative Development: An Empirical Investigation”, American Economic Review, 91(5):1369-1401.

Alesina, Alberto, Paola Giuliano and Nathan Nunn. 2013. "On the Origins of Gender Roles: Women and the Plough”, Quarterly Journal of Economics, 128(2): 469-530

Algan, Yann, Pierre Cahuc. 2010. "Inherited Trust and Growth," American Economic 
Review, 100(5): 2060-92.

Basten, Christoph and Frank Betz. 2013. "Beyond Work Ethic: Religion, Individual and Political Preferences”, American Economic Journal: Economic Policy, 5(3):67-91.

Bisin, Alberto and Thierry Verdier. 2000.

"Beyond the Melting Pot: Cultural Transmission, Marriage, and the Evolution of Ethnic and Religious Traits”, Quarterly Journal of Economics, 115 (3): 955-988.

Fishman, Raymond and Edward Miguel. 2007. “Corruption, Norms, and Legal Enforcement: Evidence from Diplomatic Parking Tickets”, Journal of Political Economy, 115(6): 1020-1048

Giuliano, Paola. 2007. "Living Arrangements in Western Europe: Does Cultural Origin Matter?” Journal of the European Economic Association, 5 (5): 927-952.

Grosjean Pauline. 2011. “The Weight of History on European Cultural Integration: A Gravity Approach” The American Economic Review, 101(3): 504 - 508

Guiso, Luigi, Paola Sapienza and Luigi Zingales. 2004. “The Role of Social Capital in Financial Development”. American Economic Review. 94(3): 526-556.

Guiso, Luigi, Paola Sapienza and Luigi Zingales. 2006. "Does Culture Affect Economic Outcomes?” Journal of Economic
Perspectives, 20 (2): 23-48.

Guiso, Luigi, Paola Sapienza and Luigi Zingales. 2008. “Long Term Persistence”, NBER WP n. 14278.

Guiso, Luigi, Paola Sapienza and Luigi Zingales, 2008 “Trusting the Stock Market” Journal of Finance, December.

Guiso, Luigi, Paola Sapienza and Luigi Zingales. 2009. "Cultural Biases in Economic Exchange?”, Quarterly Journal of Economics, 124 (3): 1095-1131.

Guiso, Luigi, Paola Sapienza and Luigi Zingales. 2014. “The Value of Corporate Culture”, Journal of Financial Economics, forthcoming.

Kreps, David. M. 1990. “Corporate Culture and Economic Theory” in Perspectives on Positive Political Economy, 90, 109-10.

Kreps, David M. 1997. “Intrinsic Motivation and Extrinsic Incentives”. American Economic Review, 87(2): 359-364.

La Porta, Rafael, Florencio Lopez-de-Silanes, Andrei Shleifer and Robert W Vishny. 1998. Law and Finance, Journal of Political Economy 106 (6): 1113-1155.

North, Douglass C. 1991.”Institutions”, Journal of Economic Perspectives, 5(1):97112.

Nunn Nathan and Leonard Wantchekon . 2011. "The Slave Trade and the Origins of Mistrust in Africa”, American Economic 
Review. 101(7): 3221-3252.

O’Reilly C. A., and Chatman, J. A. 1996.

"Culture as Social Control: Corporations,

Cults, and Commitment”, Research In

Organizational Behavior, 18 (8): 157-200.

Putam, Robert D. 1993. “Making Democracy

Work”, Princeton University Press,

Princeton.

Tabellini, Guido. 2008. "The Scope of Cooperation: Values and Incentives”, Quarterly Journal of Economics, 123(3): 905-950

Nico Voigtlander and Joachim Voth. 2012. "Persecution Perpetuated: The Medieval Origins of Anti-Semitic Violence in Nazi Germany” Quarterly Journal of Economics, 127(3):1339-1 
